\title{
Recent advances on biomass-fueled microbial fuel cell
}

\author{
Jamile Mohammadi Moradian, Zhen Fang and Yang-Chun Yong*
}

\begin{abstract}
Biomass is one of the most abundant renewable energy resources on the earth, which is also considered as one of the most promising alternatives to traditional fuel energy. In recent years, microbial fuel cell (MFC) which can directly convert the chemical energy from organic compounds into electric energy has been developed. By using MFC, biomass energy could be directly harvested with the form of electricity, the most convenient, wide-spread, and clean energy. Therefore, MFC was considered as another promising way to harness the sustainable energies in biomass and added new dimension to the biomass energy industry. In this review, the pretreatment methods for biomass towards electricity harvesting with MFC, and the microorganisms utilized in biomass-fueled MFC were summarized. Further, strategies for improving the performance of biomass-fueled MFC as well as future perspectives were highlighted.
\end{abstract}

Keywords: Biomass, Electricity generation, MFC, EAM, Sustainable energy

\section{Introduction}

In the twenty-first century, there is an urgent need for renewable energy due to the rapid depletion of fossil fuels and the increasing concerns about pollutions. Thus, various countries are looking for alternative resources such as biomass as a reliable, sustainable, and a more benign resource to reduce the demands on fossil fuels. Biomass is one of the most abundant sources among the various types of new energy sources (Alidrisi and Demirbas 2016; Menandro et al. 2017). Moreover, the use of biomass energy could be considered as a carbon-neutral process as the $\mathrm{CO}_{2}$ emission is equal to or even lower than that biomass fixed from the atmosphere. On a global scale, biomass rank fourth as an energy resource, which could provide approximately $14 \%$ of the world's energy needs (O'Mahoney et al. 2013). To date, biomass could be transformed into different kinds of energy products such as heat, gas, fuels, and electricity. Among them, electricity from biomass has been highly regarded in terms of its high capability to various aspects of life and industry (Moqsud et al. 2014). Among the various approaches

${ }^{*}$ Correspondence: ycyong@ujs.edu.cn

Biofuels Institute, School of Environment and Safety Engineering, Jiangsu University, 301 Xuefu Road, Zhenjiang 212013, China for biomass conversion to electricity, microbial fuel cells (MFC) attracted much attention due to its high theoretical energy efficiency (non-Carnot limited) and mild operation conditions requirement (Bullen et al. 2006; Mathuriya and Yakhmi 2016).

MFC can efficiently harness the energy stored in the chemical bonds of organic compounds through catalytic reactions by microorganisms, which can directly convert the chemical energy into electrical energy (Yong et al. 2013; Yu et al. 2020). MFC relies on the unique microorganism called electroactive microorganisms (EAMs) that can degrade the organic matters with diverse metabolic pathways and pass the released electrons onto the anodic electrode. The collected electrons are then transferred to the cathode through the external electric circuit and electricity is generated (Logan et al. 2006; Thygesen et al. 2011) (Fig. 1). In this case, the organic matters were directly converted into electricity with the MFCs. As this biological energy conversion process avoided the Carnot cycle (which limited the energy efficiency of thermo-electricity conversion processes), it is expected to achieve high efficiency (Hassanzadeh and Mansouri 2005). More impressively, this energy conversion process with MFC is a biological process that can be conducted in mild conditions, 


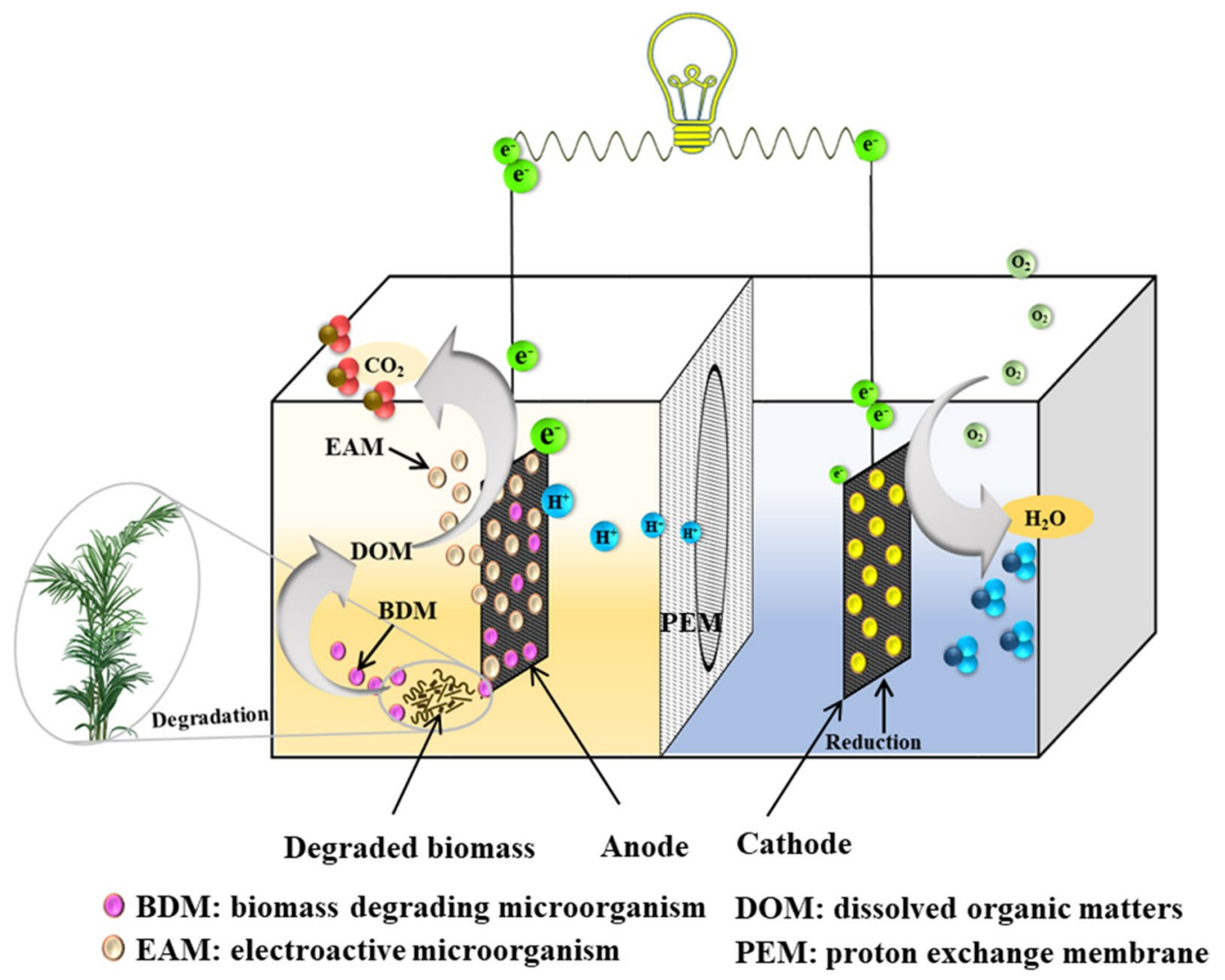

Fig. 1 Model for biomass-fueled proton exchange membrane (PEM) separated microbial fuel cell (MFC). The electroactive microorganisms (EAMs) formed EAMs biofilm and were responsible for the degradation of biomass in the anode

which makes it promising for various applications. Although the power output of MFC is still low and should be substantially improved, it already showed attractive applications as a micro-power supplier for biosensors, a long-term power supplier in remote area, deep sea, or outer space (ElMekawy et al. 2018; Ivars et al. 2018).

As biomass is an energy-rich and abundant resource, it is expected to be an ideal fuel for MFC and MFC would also be an attractive energy conversion technology for the biomass industry. Therefore, many efforts have been made to develop and optimize biomassfueled MFC during the past years. In general, as most of the microorganisms cannot directly digest biomass, pretreatment is usually required as an essential process for biomass-fueled MFC. Various EAMs for biomassfueled MFC were isolated and characterized due to EAM is the key player in electricity generation. Besides, process optimization for performance improvement of MFC also attracted much attention. In this paper, various biomass substrates and EAMs used for biomassfueled MFC were summarized, recent progress on biomass pretreatment and performance optimization for biomass-fueled MFC were also highlighted.

\section{Biomass substrates and EAMs used for biomass-fueled MFCs}

\section{Biomass substrates used in MFCs}

To date, various biomass including chitin (Li et al. 2017a, b), kitchen waste (Hou et al. 2016; Moqsud et al. 2014), orange peels (Miran et al. 2016a), algal biomass (Gajda et al. 2015; He et al. 2014), forest detritus in the forested wetland (Dai et al. 2015), wheat straw hydrolysate (Song et al. 2014; Thygesen et al. 2011), rice straw (Hassan et al. 2014), corn stove (Wang et al. 2017; Zhang et al. 2013), solid potato wastes ( $\mathrm{Du}$ and $\mathrm{Li}$ 2017; $\mathrm{Du}$ et al. 2017), food waste (ElMekawy et al. 2015; Li et al. 2016), corn stalk biomass (Liu et al. 2015), lemon peel (Miran et al. 2016b), cow dung (Bharadwaj and Kumar 2012; Javalkar and Alam 2012) has been exploited as fuel sources for bioenergy production in MFCs (Table 1). The biomass used can be categorized as lignocellulosic biomass (cellulose, hemicellulose, and lignin, such as wood, sugarcane bagasse, rice husk, rice straw, corn cob, etc.) and 


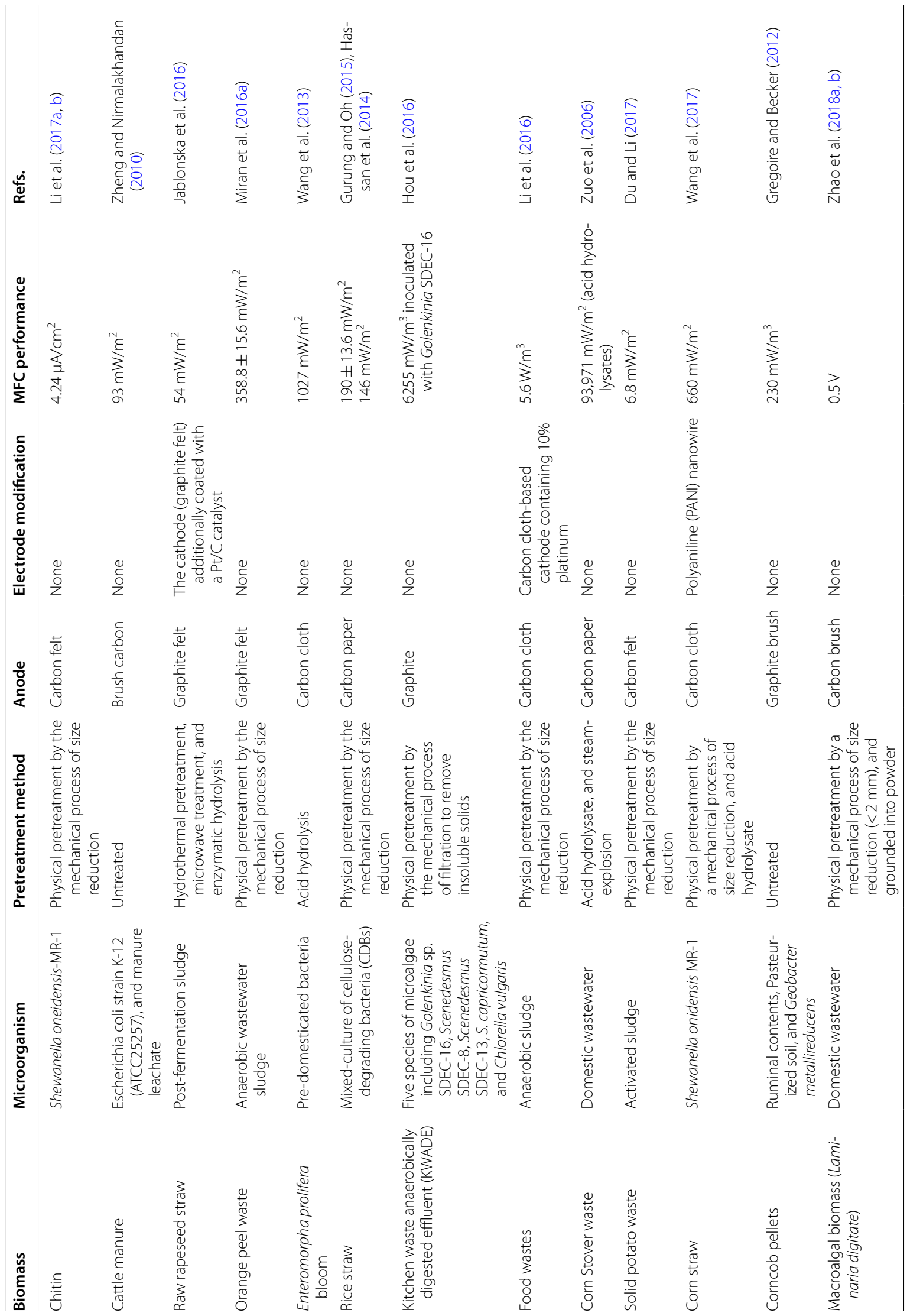




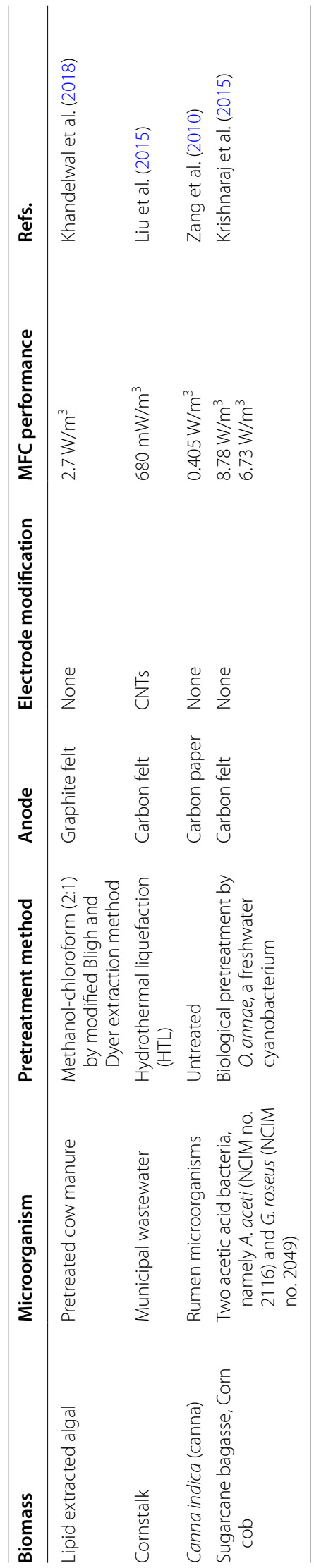


non-lignocellulosic biomass with primary components composed of lipids, proteins, starch, inorganics, and minerals. Non-lignocellulosic biomass includes sewage sludge, animal manure, algae, etc. The quality of biomass is often determined by its inherent characteristics such as moisture content, energy yield, bulk density, size, and shape (Tursi 2019), which influence the bioconversion processes and energy production capacity in MFCs. According to these researches (Table 1), most of raw biomass or organic wastes derived biomass could be exploited as fuels for MFCs, which could imply that MFC would be extensively adaptable for energy harvesting from biomass.

\section{Various EAMs used in MFCs}

EAMs based on their microbial community can differ as pure-culture, and mixed-culture. Pure-culture EAMs have been characterized with a diversity of microorganisms in MFCs belonging to three domain phyla including bacteria in the Firmicutes such as Clostridium butyricum and Actinobacteria such as Actinoalloteichus cyanogriseus, and in all classes of Proteobacteria such as Geobacter sulfurreducens, archaea such as the hyperthermophile Pyrococcus furiosus and eukaryotes such as Cystobasidium slooffiae JSUX1. Although pure-culture EAMs is useful to clarify the EET mechanism in MFCs, it requires relatively strict operating conditions and can only utilize specific compounds in hydrolysates (Cao et al. 2019). To date, various pure-culture EAMs including Gram-positive bacteria (Wrighton et al. 2011), Gram-negative bacteria (Hasan et al. 2017; Li et al. 2017a; Wang et al. 2017), yeast (Moradian et al. 2020; Sayed and Abdelkareem 2017), and even fungi (Sekrecka and Toczyłowska 2018) have been reported in the literature (Table 1). The existence of at least one EAM is required to produce energy in MFCs. However, a diversity of EAMs can contribute to more efficient energy production. In most cases, inoculated MFCs with mixed-culture such as activated sludge due to its high microbial diversity often generate much greater PD and utilize biomass hydrolysate more efficiently. Vajda et al. (2014) operated xylose (main sugar from biomass) fueled MFC using Shewanella putrefaciens and mesophilic anaerobic sludge as inoculums. Despite both pure-culture and mixed-culture MFCs were able to metabolize and generate electricity from xylose, but MFC with mixed-culture could perform higher PD. So far, investigation implied that hydrolyzed biomass can be utilized by pure-culture EAMs in MFCs, while for raw biomass without pretreatment, the inoculum for MFCs usually should be derived from mixed-culture that contained CDBs (responsible for cellulose degradation) and EAMs (responsible for electricity generation). Also, cellulose-degrading bacteria (CDBs) consortia can be used as a biocatalyst to partially degrade the lignocellulosic biomass and produce electricity. In some cases, industrial or municipal wastewater contained CDBs was also used as an active inoculum for biomass-fueled MFCs. For example, Hassan et al. (2014) developed a dual-chambered MFC fueled with rice straw without pretreatment using CDBs as biocatalyst. With an initial rice straw concentration of $1 \mathrm{~g} / \mathrm{L}$, the $\mathrm{PD}$ reached $145 \mathrm{~mW} / \mathrm{m}^{2}$ (Hassan et al. 2014).

\section{Biomass pretreatment for MFCs}

Most microorganisms are not capable of efficient hydrolysis of biomasses such as lignocellulosic biomass in the anode chamber, which results in a low PD for MFCs (Pant et al. 2010). The recalcitrance of lignocelluloses to fermentable sugars is the major technical hindrance. Especially, the hierarchical structure of biomass can resist chemical or enzymatic attack for releasing of fermentable sugars (Wegner and Jones 2009). Crystalline cellulose is highly ordered due to the existence of strong hydrogen bonding structure, which is very stable and difficult to be permeated (Klemm et al. 2005). To overcome these limitations, pretreatment processes must be used to release various reducing sugars (Fig. 2). However, the efficiency of the pretreatment is depending on the characterization of biomass, which can be considered as a factor to maximize product recovery for the biorefinery process in MFCs.

Physical pretreatment techniques operated with mechanical processes including chipping, milling, and grinding can reduce particle size, break down the crystallinity and degree of polymerization, which substantially improve the biodegradability of biomass in MFCs. It has been affirmed that the use of a fermentation media contained solid substrate gave a low PD due to slow hydrolysis of the biodegradable materials, which indicated that particle size is an essential factor for maximum derived bioenergy production. Also, it has been reported that further reduction of biomass particle size below 40 mesh has some effects on the hydroysis rates and yields, which results in a large quantity of the available material in the biodegradation process in MFCs (Agbor et al. 2011). Moreover, different types of irradiation processes (e.g., ultrasonication, electron beams, X-rays, or gamma rays) can be used for the physical pretreatment of biomass. Shen et al. (2018) reported the effect of ultrasonic pretreatment on electricity generation with dairy manure (DMMFC) as the main substrate in the DMMFC. The pretreated DMMFC obtained a maximum PD of $102 \mathrm{~mW} / \mathrm{m}^{2}$ at the ultrasonic power of $600 \mathrm{~W}$, which was $241 \%$ higher than the untreated substrate (Shen et al. 2018). Tao et al. (2013) confirmed ultrasonication could be an efficient pretreatment strategy for vegetable 


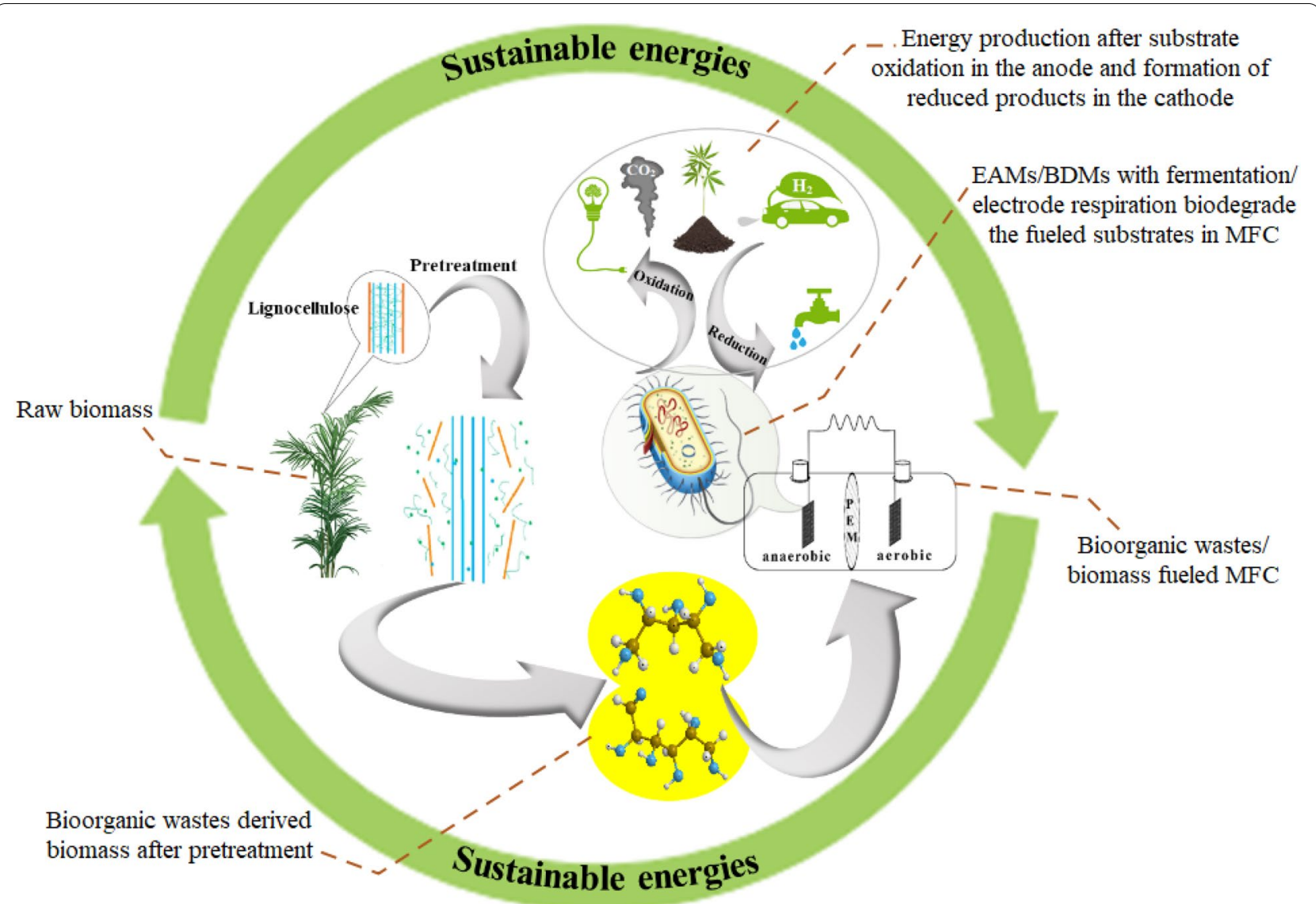

Fig. 2 Overview of processes for energy production from biomass in MFC. Pretreatment technique could break down the lignocelluloses to reducing sugars, which served the fuels for energy production by EAMs

or grass wastes. The pretreated vegetable wastes with ultrasonication at $>1.0 \mathrm{~W} / \mathrm{mL}$ could attain a maximum $\mathrm{PD}$ and COD removal of $10.19 \mathrm{~W} / \mathrm{m}^{3}$ and $62.5 \%$, respectively, while these values with the untreated sample were only $5.96 \mathrm{~W} / \mathrm{m}^{3}$ and $35.1 \%$, respectively (Tao et al. 2013).

Acidic pretreatment is one of the most commonly used methods among various chemical pretreatment techniques. Pretreatment with acid hydrolysis can improve the enzymatic hydrolysis efficiency and enhance the energy conversion efficiency of lignocellulosic biomass in MFCs. To date, these acids including concentrated mineral acid (CA), dilute mineral acid (DA) and dicarboxylic acid have been used for lignocellulosic biomass pretreatment. Among them, CA such as $\mathrm{H}_{2} \mathrm{SO}_{4}$ and $\mathrm{HCl}$ are potent agents for lignocellulosic biomass. However, these acids are toxic, corrosive, and hazardous which requires specific reactors that can resist corrosion. Meanwhile, the dilute sulfuric acid pretreatment showed high reaction rate for lignocellulose hydrolysis. Initially, two types of dilute acid hydrolysis pretreatment methods have been developed: high temperature
$\left(T>160^{\circ} \mathrm{C}\right)$ and low temperature $\left(T<160{ }^{\circ} \mathrm{C}\right)$ (Sun and Cheng 2002). Although a high temperature in the DA hydrolysis is desirable for cellulose hydrolysis, the saccharification yield is low due to sugar decomposition (McMillan 1994). Wang et al. (2017) used the diluted sulfuric acid pretreated corn straw as fuel for direct electricity generation in MFC inoculated with pure-culture. The maximum PD delivered by this MFC was $17.2 \pm 0.3 \mathrm{~mW} /$ $\mathrm{m}^{2}$, which showed the feasibility of biomass hydrolysate as the potential of electrical production using pure-culture in MFC. The combination of electrode modification and electron shuttle addition could also result in a high $\mathrm{PD}$ of $660 \mathrm{~mW} / \mathrm{m}^{2}$ from the hydrolysate with a pure-culture of Shewanella oneidensis MR-1 (Wang et al. 2017). In another study, Wang et al. (2013) pretreated Enteromorpha prolifera biomass with $2 \%$ sulfuric acid at $100{ }^{\circ} \mathrm{C}$ for $4 \mathrm{~h}$. The acid hydrolysate of $E$. prolifera biomass contained a total of $8.5 \mathrm{~g} / \mathrm{L}$ monosaccharides and had the high content of L-rhamnose $(3.74 \mathrm{~g} / \mathrm{L})$, followed by D-xylose $(2.11 \mathrm{~g} / \mathrm{L})$, D-glucose $(1.78 \mathrm{~g} / \mathrm{L})$, D-glucuronic acid $(0.581 \mathrm{~g} / \mathrm{L})$, and D-glucuronic acid lactone $(0.29 \mathrm{~g} / \mathrm{L})$. 
The PD of $1027 \mathrm{~mW} / \mathrm{m}^{2}$ at a current density of $3.8 \mathrm{~A} /$ $\mathrm{m}^{2}$ was achieved with an initial hydrolysate concentration of $1000 \mathrm{mg}$ COD/L in MFC. Also, the Coulombic efficiency (CE) and COD removal of $69.1 \%$ and $76.1 \%$ were obtained, respectively (Wang et al. 2013). Zhang et al. demonstrated that stable PD could be generated from wheat straw hydrolysate, in which the PD reached $123 \mathrm{~mW} / \mathrm{m}^{2}$ with an initial hydrolysate concentration of $1000 \mathrm{mg}$ COD/L (Zhang et al. 2009).

Alkali pretreatment involves the use of base reagents such as sodium hydroxide $(\mathrm{NaOH})$, hydrazine, anhydrous ammonia, potassium hydroxide $(\mathrm{KOH})$, or lime $\left(\mathrm{Ca}(\mathrm{OH})_{2}\right)$. Although this method can be operated at ambient temperature, the reaction time is usually long, e.g., from hours to days (Amin et al. 2017). Alkali pretreatment is preferable for low lignin content biomass such as agricultural residues/grasses, and higher lignin content substrates such as woody biomass are unsuitable for this method. Song et al. (2018) demonstrated that sodium hydroxide $(\mathrm{NaOH})$ could be used for rice straw pretreatment for a solid phase microbial fuel cell (SMFC). The SMFC with pretreated-rice straw using $\mathrm{NaOH}(5 \%)$ could retain a maximum $\mathrm{PD}$ of $140 \mathrm{~mW} / \mathrm{m}^{2}$, which was 3.6 times higher than the untreated SMFC (Song et al. 2018). Xiao et al. also confirmed the feasibility of alkaline pretreatment for sludge-fueled MFC, which was obtained a PD of $46.82-55.88 \mathrm{~mW} / \mathrm{m}^{2}$ with a fast alkaline treatment at a high concentration of sodium hydroxide (Xiao et al. 2013).

Biological/enzymatic pretreatment is a remarkable achievement that advocates a limited or no generation of toxic substances, eco-friendly process with low energy requirement, and mild operating conditions. Some bacteria and fungi producing cellulases can hydrolyze and disrupt the crystalline structure of lignocellulosic biomass and increase sugar yields to improve the performance of MFCs (Wagner et al. 2018). Bacterial species belonging to Clostridium, Cellulomonas, Bacillus, Thermomonospora, Ruminococcus, Bacteriodes, Erwinia, Acetovibrio, Microbispora, and Streptomyces can produce cellulases (Sun and Cheng 2002). White- and soft-rot fungi have been demonstrated to degrade lignocellulosic biomass. White-rot being the most effective method for biological pretreatment of biomass (Agbor et al. 2011; Sun and Cheng 2002). Brown-rot fungi can mainly attack cellulose, whereas white and soft-rot attack both lignin and cellulose via the production of enzymes (for example, lignin peroxidases, polyphenol oxidases, manganese-dependent peroxidases, and laccases)(Agbor et al. 2011). In addition to the three major types of cellulase enzymes, there are also a number of auxiliary enzymes that can attack hemicelluloses, such as glucuronidase, acetylesterase, xylanase, $\beta$-xylosidase, galactomannanase, and glucomannanase (Sun and Cheng 2002).

Nevertheless, the rate of biological hydrolysis is usually too slow. The disadvantages of this method includes the requirement of a long retention time ranging from 10 to 14 days, a careful control of growth condition avoiding contamination, and a substantial amount of space for conducting biological pretreatment are considered this method less applicable commercially. Krishnaraj et al. (2015) applied a new strategy of a novel three-chamber MFCs for simultaneous degradation of lignocellulosic biomass (sugarcane bagasse and corncob) and bioelectricity generation. The lignocellulose was first degraded by Oscillatoria annae from a freshwater cyanobacterium in the first compartment of the three-chamber MFCs. Co-culture of Oscillatoria annae and Gluconobacter roseus were used as the anodic inoculums for electricity generation using the decomposed substrates from the first chamber in MFCs. The maximum PD was $8.78 \mathrm{~W} /$ $\mathrm{m}^{3}$ and $6.73 \mathrm{~W} / \mathrm{m}^{3}$ with sugarcane bagasse and corncob as substrates, respectively (Krishnaraj et al. 2015). Also, enzymatic hydrolysis has been extensively applied for biological pretreatment. In a study, Rezaei et al. (2008) used cellulases enzyme for enzymatic hydrolysis of cellulose coupled with electricity generation in MFCs. The maximum PD with cellulases enzyme reached $100 \mathrm{~mW} /$ $\mathrm{m}^{2}$.

\section{Performance improvement for biomass-fueled MFCs}

Operation conditions and optimization

The specific metabolic process in MFCs varies on the type of biomass/organic wastes and the operational conditions of MFCs (Guo et al. 2020). In this section, operation conditions $(\mathrm{pH}$, temperature, and organic loading rate), and optimizations for performance improvement in MFCs are discussed in the following.

$p H$ is one of the essential factors in MFCs that affects both anodic microbial activities and cathodic reactions. Accumulation of protons would cause anolyte acidification, and electrolyte alkalization in the cathode chamber. Hence, reducing $\mathrm{pH}$ in the anode chamber due to increased proton concentration results in low power production, which represses the EAMs activation. On the contrary, it causes an increased $\mathrm{pH}$ in the cathode chamber that inhibits the oxygen reduction reaction (ORR) (Ivars et al. 2018). Although the use of pH buffers such as phosphate or bicarbonate ( $\mathrm{pH}$ 7.0) has been suggested for controlling $\mathrm{pH}$ at the anolyte, it may increase operating costs and effluent desalination or further phosphorous removal burden (Chen et al. 2019). It was found that an increased anodic $\mathrm{pH}$ shall attribute to an increased COD removal and improve the performance 
of MFCs. The optimal pH strongly depends on the type of microorganisms. Zhang et al. (2011) studied the effect of $\mathrm{pH}$ on the performance of MFC and anodic microbial community. Results showed a faster COD removal under acidic $\mathrm{pH}$ conditions, in which Simplicispira, Variovorax, Comamonas, and Acinetobacter were the major communities under acidic conditions. Anodic biofilm cracked and cell number greatly decreased at $\mathrm{pH} \leq 5.0$, and further, MFCs was failed at $\mathrm{pH} 4.0$ due to microbial community composition changes. However, the MFCs could recover optimal electricity generation when $\mathrm{pH}$ was further readjusted to 7.0 (Zhang et al. 2011). Optimal pH for maximum power production reported was $8-10$ in an air-cathode MFC fueled with acetate (Zhao et al. 2017). Usually, the anodic microbial reaction preferred a neutral $\mathrm{pH}$ for optimum cell growth, whereas a weak alkaline $\mathrm{pH}$ was more appropriate for cathodic reaction.

Temperature effect depends on the nature of anodic EAMs and the characteristics of biomass in MFCs. It has been reported that microorganisms can grow in four classified optimal growth temperature, i.e., psychrophiles $\left(10-15{ }^{\circ} \mathrm{C}<20{ }^{\circ} \mathrm{C}\right)$, mesophiles $\left(25-40{ }^{\circ} \mathrm{C}<45{ }^{\circ} \mathrm{C}\right)$, thermophiles $\left(50-85{ }^{\circ} \mathrm{C}\right)$, hyperthermophiles $\left(80-113{ }^{\circ} \mathrm{C}\right)$ (Stetter 2006). However, most of the characterized EAMs belong to mesophilic classification. At extremely low temperatures, microbial reactions slow down, and eventually, MFCs cannot be operated in most cases (Ivars et al. 2018). However, MFCs with psychrophiles EAMs can operate at low temperature and attain high CE. Behera et al. (2011) evaluated temperature effects on the performance of dual-chambered mediator-less MFC by adjusting the temperature between 20 and $55^{\circ} \mathrm{C}$. The highest COD removal efficiency of $84 \%$ was observed at an operating temperature of $40{ }^{\circ} \mathrm{C}$. Tee et al. (2018) studied the performance of MFC with an adsorption system (MFC-AHS) and palm oil mill effluent as a substrate under various operating temperatures. The optimum operating temperature for such a system was found at $35{ }^{\circ} \mathrm{C}$. Also, results revealed that the maximum current density could increase linearly with the temperature at a rate of $0.1772 \mathrm{~mA} / \mathrm{m}^{2} /{ }^{\circ} \mathrm{C}$, whereas maximum $\mathrm{PD}$ was in a polynomial function (Tee et al. 2018). Larrosa et al. (2010) investigated single-chambered and dual-chambered MFC operation at different temperatures ranging from 4 to $35^{\circ} \mathrm{C}$. The results revealed that the temperature as a crucial factor for COD removal and bioelectricity production, which were obtained 58\% COD removal with maximum $\mathrm{PD}$ of $15.1 \mathrm{~mW} / \mathrm{m}^{3}$ reactor $\left(8.1 \mathrm{~mW} / \mathrm{m}^{2}\right.$ cathode) at $4{ }^{\circ} \mathrm{C}$, and $94 \%$ COD removal with maximum PD of $174 \mathrm{~mW} / \mathrm{m}^{3}$ reactor $\left(92.8 \mathrm{~mW} / \mathrm{m}^{2}\right.$ cathode $)$ at $35{ }^{\circ} \mathrm{C}$ (Larrosa-Guerrero et al. 2010).

Organic loading rate $(O L R)$ has a significant impact on anodic biofilm, which primarily depends on the chemical characteristics of wastes. Especially, the fermentation of biomass/organic wastes can result in acidic metabolites production, which affects the anodic electrolyte. Therefore, the OLR fueled MFCs should be carefully optimized to achieve high performance. Further, it is confirmed that PD and CE in MFCs are closely related to OLR, in which an increased or decreased OLR can affect the efficiency of electron transfer. Operation of MFCs at the higher OLRs usually resulted in a decreased CE (Velvizhi and Mohan 2012). In a study reported for an MFC with treating leachate, the increasing OLR from 0.65 to $5.2 \mathrm{~kg} \mathrm{COD} / \mathrm{m}^{3} /$ day resulted in a decrease of overall CE from 14.4 to $1.2 \%$ (Zhang et al. 2008). Cetinkaya et al. investigated the effect of OLR with changing HRT and leachate COD concentration. The results indicated the COD removal and current density were significantly affected by increasing OLR, although the performance of MFC decreased when HRT was reduced (Cetinkaya et al. 2016).

\section{lonic conductivity of the electrolyte}

Maintaining a suitable $\mathrm{pH}$ condition of electrolyte is necessary for obtaining a high PD and CE in MFCs. Cations such as $\mathrm{Na}^{+}$and $\mathrm{K}^{+}$, other than $\mathrm{H}^{+}$are prone to transfer toward the cathode, however, $\mathrm{H}^{+}$mass transport is sluggish, which its accumulation in the anode causes anolyte acidification, and significantly restricts the electricity generation in the MFCs (Ren et al. 2017). Eliminating the anolyte acidification with alkaline catholyte through electrolyte recirculation has relieved the $\mathrm{pH}$ decline in MFCs, whilst $\mathrm{O}_{2}$ was likely to be influenced to the anode and restricted the activity of anode biofilm (Zhang et al. 2015). Further, inorganic ions buffers are always indispensable in MFCs to provide certain ionic conductivity and maintain stable $\mathrm{pH}$ conditions of the electrolyte (Chen et al. 2019). In addition, inorganic carbons (IC) such as $\mathrm{H}_{2} \mathrm{CO}_{3}$ (dissolved $\mathrm{CO}_{2}$ ), $\mathrm{HCO}_{3}^{-}, \mathrm{CO}_{3}{ }^{-2}$ could be produced as the final metabolites of MFC, which are considered as endogenous buffers, although their accumulation concentration is insufficient to prevent acidification of anolyte (Ren et al. 2017). To overcome this limitation, Ren et al. (2017) reported a novel buffer-free MFC with anolyte recycling as a feasible strategy that could increase the IC concentration of the anolyte, thoroughly eliminating anolyte acidification and dramatically enhancing the electric power of MFCs.

\section{Electrode modification}

Electrode materials should possess good electron conductivity, large surface area and good biocompability for microbial adherence. The surface properties of an electrode, such as roughness, porosity, and surface hydrophilicity can affect the formation of biofilm and 
subsequently derived electric power in MFCs (Zhao et al. 2017). In recent decades, carbonaceous is the most extensively used anodic material in MFCs. Carbonaceous-based materials such as carbon paper (Hassan et al. 2014), granular graphite (Habibul et al. 2016; Vilajeliu et al. 2017), and graphite rods (Xu et al. 2015) have been identified and widely used in biomass-fueled MFCs. However, the commercial carbon-based electrode showed a smooth surface with low electrochemical activity and biocompatibility. Hence, various strategies for electrode surface modification have been developed. For example, Chen et al. (2018) developed the candle soot modified-CC electrode by inoculating Aeromonas hydrophila NIU01 in MFCs. The modification with 60-s could alter the hydrophobic surfaces of the CC electrodes to super-hydrophilic. Further, the electrochemical measurement of the modified electrode exhibited the highest PD of $19.8 \pm 0.2 \mathrm{~mW} / \mathrm{m}^{2}$ with an internal resistance of $619 \Omega$, which was higher than that of MFCs conducted with the bare electrodes $\left(10.2 \pm 0.2 \mathrm{~mW} / \mathrm{m}^{2}\right.$ ) (Chen et al. 2018). In another study, Zhao et al. (2018a, b) thermally modified CF electrodes with a mixed solution of concentrated $\mathrm{HNO}_{3}$ and $30 \% \mathrm{H}_{2} \mathrm{O}_{2}$ in different volume ratios. The inoculum of MFCs was supplied from local domestic sewage. The modification decreased the anodic charge transfer resistance with a maximum PD of $785.2 \mathrm{~mW} /$ $\mathrm{m}^{2}$, which was $51.1 \%$ higher than the bare electrodes in the MFCs (Zhao et al. 2018a, b). Moreover, modification with conductive polymers such as polypyrrole and polyaniline was demonstrated for improving anodic biofilm formation. The polymer composites can increase electrode surface roughness, and also the presence of cationic nitrogenous groups in their composite structure can enhance cellular adhesion electrostatically (Fogel and Limson 2016). For example, Li et al. (2018) introduced the polypyrrole nanowires coated by graphene oxide (PPyNWs/GO) using a one-step electrochemical method. The performance of PPy-NWs/GO showed higher PD than PPy-NWs. Besides, the PPy-NWs/GO showed a more extensive biofilm of microbial attachment, which was owing to the GO nanosheet ( $\mathrm{Li}$ et al. 2018). Razalli et al. (2017) pretreated the extracted crystalline nanocellulose of semantan bamboo with acid hydrolysis to synthesize a polyaniline/crystalline nanocellulose (PANI/CNC) electrode via in situ oxidative polymerization of aniline. The EIS results of PANI/CNC displayed a lower value of $R_{\mathrm{CT}}\left(148 \Omega \mathrm{cm}^{2}\right)$ compared to the bare $\left(177 \Omega \mathrm{cm}^{2}\right)$ and PANI $\left(156 \Omega \mathrm{cm}^{2}\right)$ electrodes, which revealed that PANI/ $\mathrm{CNC}$ incorporation could significantly reduce the charge transfer rate (Razalli et al. 2017). Moreover, nanoparticles, through a combination of the improved electrode surface, alteration of surface chemistry, and the presentation of electroactive moieties to the microbial cells have been used for improvements of the electrical current in MFCs (Fogel and Limson 2016). Ni, Pd, Au, and $\mathrm{Fe}_{2} \mathrm{O}_{3}$ nanoparticles have been used to enhance the direct EET for performance improvement of MFCs (Fogel and Limson 2016). Further, carbon-based nanomaterials including carbon nanotubes (CNTs), carbon nanoparticles, and graphene have also been performed for improving cell/ electrode interaction, and enhancing EET pathway in MFCs. Besides, the rational inclusion of nanomaterials as electrode material/modifiers could significantly improve the electricity generation of biomass-fueled MFCs. Graphene oxide (GO) with rich hydrophilic functional groups and possessing biocompatibility, superior electrical, mechanical, and optical properties has developed a strong electrochemical performance in MFCs (Yong et al. 2014). GO can react with organic or inorganic chemicals and to remove the oxygen atoms to form proxy groups, which results in reduced graphene oxide $(\mathrm{rGO})$ sheet network. However, apart from chemical reduction of $\mathrm{GO}$, there are many techniques (i.e., hydrothermal reduction, electrochemical reduction, solvothermal reduction, and microbial reduction) that can react with $\mathrm{GO}$ and expose the conjugated $s p$ network and degrade the electrical properties of the GO dispersion to form rGO nanosheet (Yong et al. 2014). Nevertheless, the toxicity of some agents cannot be neglected. For example, chemical reduction requires a potent reducing reagent such as hydrazine hydrate $\left(\mathrm{N}_{2} \mathrm{H}_{4}\right)$, which is a highly corrosive material. Hence, the new strategies of GO reduction with biocompatible property and under mild-condition have been considered in recent studies. For example, Goto et al. (2015) reported the effect of GO on SMFCs (sediment) and PMFCs (plant) at different concentrations. Findings revealed a biological GO reduction after 10 days in GO-SMFCs under anaerobic incubation. The highest PD of GO-SMFCs containing $1.0 \mathrm{~g} / \mathrm{kg}$ of GO was $40 \pm 19 \mathrm{~mW} / \mathrm{m}^{2}$. On the contrary, the GO reduction in PMFCs was much slower than GO-SMFCs, which exhibited a reduction in $\mathrm{GO}$ after 27 days of operation time (Goto et al. 2015).

\section{Biocathode}

Biocathode offers biocompatible, cost-effective, and promising material for many applications such as heavy metal removal and waste treatment. The use of biocathodes eliminates the need for expensive construction material and potentially toxic chemicals as catholyte, and further the necessity for their recycling and safe disposal (Gude et al. 2013). Algae play a crucial role in nitrogen and phosphorus cycles in waters. The use of algae to produce oxygen is being considered for exploiting its feasibility as an oxygen supplier for cathodic reaction in MFCs. In order, the produced $\mathrm{CO}_{2}$ by anode 
through biomass oxidation would be transferred to the cathode as a carbon source for algae growth by the photosynthesis process. Cui et al. (2014) utilized Chlorella vulgaris as biocathode. The maximum $\mathrm{PD}$, and $\mathrm{CE}$ at $2500 \mathrm{mg} \mathrm{COD} / \mathrm{L}$ could be obtained $1926 \pm 21.4 \mathrm{~mW} /$ $\mathrm{m}^{2}$ and $6.3 \pm 0.2 \%$, respectively. The use of biocathode would significantly reduce the cost of MFC and expand its applications (e.g., $\mathrm{CO}_{2}$ fixation, microalgae cultivation) in biomass-fueled MFC.

\section{Genetically engineered microorganisms}

Molecular biology techniques helped to clarify the pathways for electron transfer steps and also provide the possiblity to engineer microorganisms to use biomass as fuels for electricity generation. So far, various technical approaches including random approaches (i.e., directed evolution of redox enzymes, and silver/gold coating of cells), rational design (i.e., heterologous gene expression, engineering of metabolic processes, and engineering of bacterial pili), and de-novo design (i.e., bacterial surface display of redox proteins, yeast surface display of redox proteins, and hybrid MFC-enzyme based fuel cells) have been investigated for the genomic engineering of a novel or optimized biocatalysis in MFCs (Alfonta 2010; Zhao et al. 2020). Recently, Li et al. (2019) designed a bioengineered microbial consortium of Klebsiella pneumonia-S. oneidensis for efficiently harvesting of the electricity from corn stalk hydrolysate. The eliminating of the ethanol and acetate pathway via deleting pta (phosphotransacetylase gene) and $a d h E$ (alcohol dehydrogenase gene) genes could reinforce the lactate production in K. pneumoniae. Also, a biosynthesis and delivery system for transporting lactate was assembled in this strain through expressing $l d h D$ (lactate dehydrogenase gene) and $l l d P$ (lactate transporter gene). Thus, the engieered $K$. pneumoniae could ferment the hydrolysate to lactate as fuel for electricity generation by $S$. oneidensis. Furthermore, to improve the EET efficiency of S. oneidensis, a heterogenous flavins synthesis pathway from Bacillus subtilis was expressed in S. oneidensis. The genetically engineered microbial consortia showed high efficiency for electricity generation from biomass hydrolysate (Li et al. 2019). These findings demonstrate genetic engineered microorganisms would be promising to be adapted for biomassfueled MFCs.

\section{Coproduction of electricity with other energy products}

It is well known that biorefinery of biomass only can harvest a limited fraction of the energy in the biomass, leading to low energy efficiency and a large quantity of wastes. It is a highly innovative approach in MFCs that electricity can be coproduced with other energy products, which can substantially improve the overall energy efficiency for biomass conversion with MFCs. It is reported that MFCs can further recovery the energy from the waste of biomass biorefinery (Offei et al. 2019). For example, a novel biorefinery approach involved the coproduction of bioethanol and electricity production from tropical seaweeds has been developed (Offei et al. 2019). The seaweed biomass was first used for bioethanol fermentation and then the bioethanol production residues were employed for bioelectricity generation in MFC. This combination process achieved coproduction of bioethanol as high as $5.1 \mathrm{~g} / 100 \mathrm{~g}$ dry biomass and $0.5 \mathrm{~W} / \mathrm{m}^{3}$ power density, which also reduced waste to $24.4 \%$ from 69 to $79 \%$ for seaweed bioethanol production alone. More recently, the strategy of isolation and acclimation of a new exoelectrogenic yeast strain (Cystobasidium slooffiae JSUX1) could produce significant bioelectricity and biohydrogen production simultaneously with rapid xylose (secondary dominant sugar derived from biomass) metabolism in MFC, in which the produced electrons were harvested from $\mathrm{H}_{2}$ fermentation with xylose (Moradian et al. 2020). The coproduction of electricity and $\mathrm{H}_{2}$ is of great interest for application as these two energy products are obtained in a single operated MFC, which would significantly reduce the cost of reactor and operation.

\section{Conclusions and perspectives}

Biomass is one of the most abundant renewable energy resources on the earth. Conversion of the biomass directly into the most conventional electric energy is considered a promising roadmap for the biomass energy industry. In recent years, it was found that MFCs could directly convert the biomass into electricity with high energy efficiency, which could bypass the Carnot limitation. Therefore, various biomass-fueled MFCs have been developed and were extensively studied. Raw biomass is hard to be metabolized by EAMs. Thus, a variety of pretreatment techniques employed to degrade the lignocellulosic biomass and release the carbohydrates products. The integration of the pretreatment steps not only improve CE, but also broaden the substrate spectrum for biomass-fueled MFCs. Since EAMs are the key player for energy conversion in MFCs, various types of EAMs including Gram-negative and Gram-positive bacteria, yeast, fungi, and mixedculture from activated sludge were used as inoculum for biomass-fueled MFCs. Usually, unsuitable EAMs for biodegradation/biorefinery in MFCs cause a large quantity of non-oxidized substrates, which results in a low CE output in MFCs. Therefore, the selection of a suitable EAM and selection of preferred substrate are 
suggested for improved EC of biomass-fueled MFCs. Further, for complex biomass, constructing MFCs with diverse biocatalysis of EAMs in a single MFC can be suggested for enhancing CE in biomass-fueled MFCs. Also, operation conditions and optimization can significantly affect the performance of biomassfueled MFCs. The current review focused on optimization parameters for MFCs performance improvement, while insights into the mechanism for biomass energy conversion and electron transportation are still very limited, which requires further exploration. Besides, detailed Omics and functional analysis, genome mining of the microbial community for biomass-fueled MFCs are expected, which holds a great promise to explore new EAMs species and new functional genes/clusters/ proteins. Moreover, synthetic consortium or artificial superbug integrating the functions of biomass degradation, saccharification, and bioelectricity conversion are expected to be developed, which would result in a consolidated process and surely simplify the process for biomass-fueled MFCs. Systematic process optimizations with special consideration of the unique features of biomass fuels and practical applications are still required. Finally, new process design and scale-up research are urgently needed, which would be essential for practical applications.

\begin{abstract}
Abbreviations
BDMs: Biomass-degrading microorganisms; CA: Concentrated mineral acid; CC: Carbon cloth; CDBs: Cellulose-degrading bacteria; CE: Coulombic efficiency; CF: Carbon felt; CNTs: Carbon nanotubes; COD: Chemical oxygen demand; DA: Dilute mineral acid; DMMFC: Dairy manure microbial fuel cell; DOM: Dissolved organic matters; EAM: Electroactive microorganism; EET: Extracellular electron transfer; EIS: Electrochemical impedance spectroscopy; GO: Graphene oxide; HRT: Hydraulic retention time; HTL: Hydrothermal liquefaction; KWADE: Kitchen waste anaerobically digested effluent; MFC: Microbial fuel cell; OLR: Organic loading rate; PANI/CNC: Polyaniline/crystalline nanocellulose; PD: Power density; PEM: Proton exchange membrane; PMFC: Plant microbial fuel cell; PPy: Polypyrrole; rGO: Reduced graphene oxide; SMFC: Sediment microbial fuel cell.

\section{Acknowledgements}

This work was supported by the National Natural Science Foundation of China (NSFC 31870112 and 21908083), Natural Science Foundation of Jiangsu Province (BK20190868), 333 Program of Jiangsu Province (BRA2020299), Independent Innovation Program for Agricultural Science and Technology of Jiangsu Province (CX(20)2014) and a Project of Faculty of Agricultural Equipment of Jiangsu University.
\end{abstract}

\section{Authors' contributions}

$J M M$ and $Y C Y$ conceived and wrote the manuscript. JMM, ZF and YCY revised the manuscript. All authors read and approved the final manuscript.

\section{Funding}

National Natural Science Foundation of China, Natural Science Foundation of Jiangsu Province, 333 program of Jiangsu Province and a Project of Faculty of Agricultural Equipment of Jiangsu University.

\section{Availability of data and materials} Not applicable.
Ethics approval and consent to participate Not applicable.

\section{Competing interests}

The authors declare that they have no competing interests.

Received: 6 December 2020 Accepted: 25 January 2021

Published online: 09 February 2021

\section{References}

Agbor VB, Cicek N, Sparling R, Berlin A, Levin DB (2011) Biomass pretreatment: fundamentals toward application. Biotechnol Adv 29:675-685. https:// doi.org/10.1016/j.biotechadv.2011.05.005

Alidrisi H, Demirbas A (2016) Enhanced electricity generation using biomass materials. Energy Source A 38:1419-1427. https://doi.org/10.1080/15567 036.2014 .948647

Alfonta L (2010) Genetically engineered microbial fuel cells. Electroanalysis 22:822-831. https://doi.org/10.1002/elan.200980001

Amin FR, Khalid H, Zhang H, u Rahman S, Zhang R, Liu G, Chen C (2017) Pretreatment methods of lignocellulosic biomass for anaerobic digestion. AMB Express 7:72. https://doi.org/10.1186/s13568-017-0375-4

Behera M, Murthy S, Ghangrekar M (2011) Effect of operating temperature on performance of microbial fuel cell. Water Sci Technol 64(4):917-922. https ://doi.org/10.2166/wst.2011.704

Bharadwaj SK, Kumar HD (2012) A study on the electricity generation from cow dung using microbial fuel cell. J Biochem Technol 3:442-447

Bullen RA, Arnot T, Lakeman J, Walsh F (2006) Biofuel cells and their development. Biosens Bioelectron 21:2015-2045. https://doi.org/10.1016/j. bios.2006.01.030

Cao Y, Mu H, Liu W, Zhang R, Guo J, Xian M, Liu H (2019) Electricigens in the anode of microbial fuel cells: pure cultures versus mixed communities. Microb Cell Fact 18(1):1-14. https://doi.org/10.1186/s12934-019-1087-z

Cetinkaya AY, Ozkaya B, Taskan E, Karadag D, Cakmakci M (2016) The production of electricity from dual-chambered microbial fuel cell fueled by old age leachate. Energy Source A 38:1544-1552. https://doi. org/10.1080/15567036.2013.843041

Chen BY, Tsao YT, Chang SH (2018) Cost-effective surface modification of carbon cloth electrodes for microbial fuel cells by candle soot coating. Coatings 8:468. https://doi.org/10.3390/coatings8120468

Chen J, LV Y, Wang Y, Ren Y, Li X, Wang X (2019) Endogenous inorganic carbon buffers accumulation and self-buffering capacity enhancement of aircathode microbial fuel cells through anolyte recycling. Sci Total Environ 676:11-17. https://doi.org/10.1016/j.scitotenv.2019.04.282

Cui Y, Rashid N, Hu N, Rehman MSU, Han JI (2014) Electricity generation and microalgae cultivation in microbial fuel cell using microalgae-enriched anode and bio-cathode. Energy Convers Manag 79:674-680. https://doi. org/10.1016/j.enconman.2013.12.032

Dai J, Wang JJ, Chow AT, Conner WH (2015) Electrical energy production from forest detritus in a forested wetland using microbial fuel cells. GCB Bioenergy 7:244-252. https://doi.org/10.1111/gcbb.12117

Du H, Li F (2017) Enhancement of solid potato waste treatment by microbial fuel cell with mixed feeding of waste activated sludge. J Clean Prod 143:336-344. https://doi.org/10.1016/j.jclepro.2016.12.104

Du H, Li F, Huang K, Li W, Feng C (2017) Potato waste treatment by microbial fuel cell. Evaluation based on electricity generation, organic matter removal and microbial structure. Environ Prot Eng 43:5-18. https://doi. org/10.37190/EPE170101

EIMekawy A, Srikanth S, Bajracharya S, Hegab HM, Nigam PS, Singh A, Mohan SV, Pant D (2015) Food and agricultural wastes as substrates for bioelectrochemical system (BES): the synchronized recovery of sustainable energy and waste treatment. Food Res Int 73:213-225. https://doi. org/10.1016/j.foodres.2014.11.045

EIMekawy A, Hegab HM, Pant D, Saint CP (2018) Bio-analytical applications of microbial fuel cell-based biosensors for onsite water quality monitoring. J Appl Microbiol 124:302-313. https://doi.org/10.1111/ jam. 13631

Fogel R, Limson J (2016) Applications of nanomaterials in microbial fuel cells. Nanomaterials for fuel cell catalysis. Springer, Cham, pp 551-575. https://doi.org/10.1007/978-3-319-29930-3_14 
Gajda I, Greenman J, Melhuish C, leropoulos I (2015) Self-sustainable electricity production from algae grown in a microbial fuel cell system. Biomass Bioenergy 82:87-93. https://doi.org/10.1016/j.biomb ioe.2015.05.017

Goto Y, Yoshida N, Umeyama Y, Yamada T, Tero R, Hiraishi A (2015) Enhancement of electricity production by graphene oxide in soil microbial fuel cells and plant microbial fuel cells. Front Bioeng Biotechnol 3:42. https:// doi.org/10.3389/fbioe.2015.00042

Gregoire K, Becker J (2012) Design and characterization of a microbial fuel cell for the conversion of a lignocellulosic crop residue to electricity. Bioresour Technol 119:208-215. https://doi.org/10.1016/j.biortech.2012.05.075

Gude V, Kokabian B, Gadhamshetty V (2013) Beneficial bioelectrochemical systems for energy, water, and biomass production. J Microb Biochem Technol 6:1-14. https://doi.org/10.4172/1948-5948.S6-005

Guo Y, Wang J, Shinde S, Wang X, Li Y, Dai Y, Ren J, Zhang P, Liu X (2020) Simultaneous wastewater treatment and energy harvesting in microbial fuel cells: an update on the biocatalysts. RSC Adv 10:25874-25887. https://doi. org/10.1039/D0RA05234E

Gurung A, Oh SE (2015) Rice straw as a potential biomass for generation of bioelectrical energy using microbial fuel cells (MFCs). Energy Sources A 37:2625-2631. https://doi.org/10.1080/15567036.2012.728678

Habibul N, Hu Y, Wang Y-K, Chen W, Yu H-Q, Sheng G-P (2016) Bioelectrochemical chromium(VI) removal in plant-microbial fuel cells. Environ Sci Technol 50:3882-3889. https://doi.org/10.1021/acs.est.5b06376

Hasan K, Grattieri M, Wang T, Milton RD, Minteer SD (2017) Enhanced bioelectrocatalysis of Shewanella oneidensis MR-1 by a naphthoquinone redox polymer. ACS Energy Lett 2:1947-1951. https://doi.org/10.1021/acsen ergylett.7b00585

Hassan SH, El-Rab SMG, Rahimnejad M, Ghasemi M, Joo JH, Sik OY, Kim IS, Oh SE (2014) Electricity generation from rice straw using a microbial fuel cell. Int J Hydrog Energy 39:9490-9496. https://doi.org/10.1016/j.ijhyd ene.2014.03.259

Hassanzadeh H, Mansouri S (2005) Efficiency of ideal fuel cell and carnot cycle from a fundamental perspective. Proc Inst Mech Eng A 219:245-254. https://doi.org/10.1243/F095765005X28571

He H, Zhou M, Yang J, Hu Y, Zhao Y (2014) Simultaneous wastewater treatment, electricity generation and biomass production by an immobilized photosynthetic algal microbial fuel cell. Bioprocess Biosyst Eng 37:873-880. https://doi.org/10.1007/s00449-013-1058-4

Hou Q, Nie C, Pei H, Hu W, Jiang L, Yang Z (2016) The effect of algae species on the bioelectricity and biodiesel generation through open-air cathode microbial fuel cell with kitchen waste anaerobically digested effluent as substrate. Bioresour Technol 218:902-908. https://doi.org/10.1016/j.biort ech.2016.07.035

Ivars BF, Zuliani A, Fallah M, Mashkour M, Rahimnejad M, Luque R (2018) Novel applications of microbial fuel cells in sensors and biosensors. Appl Sci 8:1184. https://doi.org/10.3390/app8071184

Jablonska MA, Rybarczyk MK, Lieder M (2016) Electricity generation from rapeseed straw hydrolysates using microbial fuel cells. Bioresour Technol 208:117-122. https://doi.org/10.1016/j.biortech.2016.01.062

Javalkar PD, Alam J (2012) Comparative study on sustainable bioelectricity generation from microbial fuel cell using bio-waste as fuel. IJSRP 3(8):1-6

Khandelwal A, Vijay A, Dixit A, Chhabra M (2018) Microbial fuel cell powered by lipid extracted algae: a promising system for algal lipids and power generation. Bioresour Technol 247:520-527. https://doi.org/10.1016/j. biortech.2017.09.119

Klemm D, Heublein B, Fink HP, Bohn A (2005) Cellulose: fascinating biopolyme and sustainable raw material. Angew Chem Int Ed 44:3358-3393. https:// doi.org/10.1002/anie.200460587

Krishnaraj RN, Berchmans S, Pal P (2015) The three-compartment microbial fuel cell: a new sustainable approach to bioelectricity generation from lignocellulosic biomass. Cellulose 22:655-662. https://doi.org/10.1007/ s10570-014-0463-4

Larrosa-Guerrero A, Scott K, Head I, Mateo F, Ginesta A, Godinez C (2010) Effect of temperature on the performance of microbial fuel cells. Fuel 89:3985-3994. https://doi.org/10.3303/CET1021078

Li H, Tian Y, Zuo W, Zhang J, Pan X, Li L, Su X (2016) Electricity generation from food wastes and characteristics of organic matters in microbial fuel cell. Bioresour Technol 205:104-110. https://doi.org/10.1016/j.biort ech.2016.01.042
Li S-W, He H, Zeng RJ, Sheng G-P (2017a) Chitin degradation and electricity generation by Aeromonas hydrophila in microbial fuel cells. Chemosphere 168:293-299. https://doi.org/10.1016/j.chemosphere.2016.10.080

Li SW, Zeng RJ, Sheng GP (2017b) An excellent anaerobic respiration mode for chitin degradation by Shewanella oneidensis MR-1 in microbial fuel cells. Biochem Eng J 118:20-24. https://doi.org/10.1016/j.bej.2016.11.010

Li X, Qian J, Guo X, Shi L (2018) One-step electrochemically synthesized graphene oxide coated on polypyrrole nanowires as anode for microbial fuel cell. 3 Biotech 8:375. https://doi.org/10.1007/s13205-018-1321-0

Li F, An X, Wu D, Xu J, Chen Y, Li W, Cao Y, Guo X, Lin X, Li C (2019) Engineering microbial consortia for high-performance cellulosic hydrolyzates-fed microbial fuel cells. Front Microbiol 10:409. https://doi.org/10.3389/fmicb 2019.00409

Liu Z, He Y, Shen R, Zhu Z, Xing XH, Li B, Zhang Y (2015) Performance and microbial community of carbon nanotube fixed-bed microbial fuel cell continuously fed with hydrothermal liquefied cornstalk biomass. Bioresour Technol 185:294-301. https://doi.org/10.1016/j.biortech.2015.03.021

Logan BE, Hamelers B, Rozendal R, Schröder U, Keller J, Freguia S, Aelterman P, Verstraete W, Rabaey K (2006) Microbial fuel cells: methodology and technology. Environ Sci Technol 40:5181-5192. https://doi.org/10.1021/ es0605016

Mathuriya AS, Yakhmi J (2016) Microbial fuel cells_-applications for generation of electrical power and beyond. Crit Rev Microbiol 42:127-143. https:// doi.org/10.3109/1040841x.2014.905513

McMillan JD (1994) Pretreatment of lignocellulosic biomass. Enzymatic conversion of biomass for fuels production, vol 556. ACS Publications, Washington, pp 292-324. https://doi.org/10.1021/bk-1994-0566.ch015

Menandro LMS, Cantarella H, Franco HCJ, Kolln OT, Pimenta MTB, Sanches GM, Rabelo SC, Carvalho JLN (2017) Comprehensive assessment of sugarcane straw: implications for biomass and bioenergy production. Biofuel Bioprod Biorefin 11:488-504. https://doi.org/10.1002/bbb.1760

Miran W, Nawaz M, Jang J, Lee DS (2016a) Conversion of orange peel waste biomass to bioelectricity using a mediator-less microbial fuel cell. Sci Total Environ 547:197-205. https://doi.org/10.1016/j.scitotenv.2016.01.004

Miran W, Nawaz M, Jang J, Lee D-S (2016b) Sustainable electricity generation by biodegradation of low-cost lemon peel biomass in a dual chamber microbial fuel cell. Int Biodeter Biodegrad 106:75-79. https://doi. org/10.1016/j.ibiod.2015.10.009

Moqsud MA, Omine K, Yasufuku N, Bushra QS, Hyodo M, Nakata Y (2014) Bioelectricity from kitchen and bamboo waste in a microbial fuel cell. Waste Manag Res 32:124-130. https://doi.org/10.1177/0734242X13517160

Moradian JM, Xu ZA, Shi YT, Fang Z, Yong YC (2020) Efficient biohydrogen and bioelectricity production from xylose by microbial fuel cell with newly isolated yeast of Cystobasidium slooffiae. Int J Energy Res 44:325-333. https://doi.org/10.1002/er.4922

O'Mahoney A, Thorne F, Denny E (2013) A cost-benefit analysis of generating electricity from biomass. Energy Policy 57:347-354. https://doi. org/10.1016/j.enpol.2013.02.005

Offei F, Mensah M, Kemausuor F, Thygesen A (2019) A biorefinery approach to bioethanol and bioelectricity co-production from tropical seaweeds. J Appl Phycol 31:3899-3913. https://doi.org/10.1007/s10811-019-01887-6

Pant D, Van Bogaert G, Diels L, Vanbroekhoven K (2010) A review of the substrates used in microbial fuel cells (MFCs) for sustainable energy production. Bioresour Technol 101:1533-1543. https://doi.org/10.1016/j. biortech.2009.10.017

Ren YP, Chen JL, Shi YG, Li XF, Yang N, Wang XH (2017) Anolyte recycling enhanced bioelectricity generation of the buffer-free single-chamber air-cathodemicrobial fuel cell. Bioresour Technol 244(1):1183-1187. https ://doi.org/10.1016/j.biortech.2017.08.073

Razalli RL, Abdi MM, Tahir PM, Moradbak A, Sulaiman Y, Heng LY (2017) Polyaniline-modified nanocellulose prepared from Semantan bamboo by chemical polymerization: preparation and characterization. RSC Adv 7:25191-25198. https://doi.org/10.1039/C7RA03379F

Rezaei F, Richard TL, Logan BE (2008) Enzymatic hydrolysis of cellulose coupled with electricity generation in a microbial fuel cell. Biotechnol Bioeng 101:1163-1169. https://doi.org/10.1002/bit.22015

Sayed ET, Abdelkareem MA (2017) Yeast as a biocatalyst in microbial fuel cell. Old yeasts-new questions. Rijeka, InTech, pp 41-65. https://doi. org/10.5772/intechopen.70402

Sekrecka BA, Toczyłowska MR (2018) Fungi-based microbial fuel cells. Energies 11:2827. https://doi.org/10.3390/en11102827 
Shen J, Wang C, Liu Y, Hu C, Xin Y, Ding N, Su S (2018) Effect of ultrasonic pretreatment of the dairy manure on the electricity generation of microbial fuel cell. Biochem Eng J 129:44-49. https://doi.org/10.1016/j. bej.2017.10.013

Song TS, Wang D-B, Han S, Wu XY, Zhou CC (2014) Influence of biomass addition on electricity harvesting from solid phase microbial fuel cells. Int J Hydrog Energy 39:1056-1062. https://doi.org/10.1016/j.ijhyd ene.2013.10.125

Song TS, Hou S, Zhang J, Wang H, Xie J (2018) Production of electricity from rice straw with different pretreatment methods using a sediment microbial fuel cell. Int J Electrochem Sci 13:461-471. https://doi.org/10.20964 /2018.01.28

Stetter KO (2006) Hyperthermophiles in the history of life. Philos Trans R Soc B 361:1837-1843. https://doi.org/10.1098/rstb.2006.1907

Sun Y, Cheng J (2002) Hydrolysis of lignocellulosic materials for ethanol production: a review. Bioresour Technol 83:1-11. https://doi.org/10.1016/ S0960-8524(01)00212-7

Tao K, Quan X, Quan Y (2013) Composite vegetable degradation and electricity generation in microbial fuel cell with ultrasonic pretreatment. Environ Eng Manag J 12:1423-1427. https://doi.org/10.30638/eemj.2013.175

Tee PF, Abdullah MO, Tan IA, Amin MA, Nolasco H-C, Bujang K (2018) Bioenergy generation in an affordable, single-chamber microbial fuel cell integrated with adsorption hybrid system: effects of temperature and comparison study. Environ Technol 39:1081-1088. https://doi. org/10.1080/09593330.2017.1320433

Thygesen A, Poulsen FW, Angelidaki I, Min B, Bjerre A-B (2011) Electricity generation by microbial fuel cells fuelled with wheat straw hydrolysate. Biomass Bioenergy 35:4732-4739

Tursi A (2019) A review on biomass: importance, chemistry, classification, and conversion. Biofuel Res J 6:962-979. https://doi.org/10.18331/BRJ20 19.6.2.3

Vajda B, Nemestothy N, Bakonyi P, Belafi BK (2014) Xylose substrate as the only nutrient in the operation of microbial fuel cells. Environ Prot Eng 40:131-141. https://doi.org/10.5277/epe140210

Velvizhi G, Mohan SV (2012) Electrogenic activity and electron losses under increasing organic load of recalcitrant pharmaceutical wastewater. Int J Hydrog Energy 37:5969-5978. https://doi.org/10.1016/j.ijhyd ene.2011.12.112

Vilajeliu PA, Puig S, Salcedo DI, Balaguer M, Colprim J (2017) Long-term assessment of six-stacked scaled-up MFCs treating swine manure with different electrode materials. Environ Sci Water Res Technol 3:947-959. https://doi. org/10.1039/C7EW00079K

Wagner AO, Lackner N, Mutschlechner M, Prem EM, Markt R, Illmer P (2018) Biological pretreatment strategies for second-generation lignocellulosic resources to enhance biogas production. Energies 11:1-14. https://doi. org/10.3390/en11071797

Wang M, Yan Z, Huang B, Zhao J, Liu R (2013) Electricity generation by microbial fuel cells fuelled with Enteromorpha prolifera hydrolysis. Int $J$ Electrochem Sci 8:2104-2111

Wang YZ, Shen Y, Gao L, Liao ZH, Sun JZ, Yong YC (2017) Improving the extracellular electron transfer of Shewanella oneidensis MR-1 for enhanced bioelectricity production from biomass hydrolysate. RSC Adv 7:3048830494. https://doi.org/10.1039/C7RA04106C

Wegner TH, Jones EP (2009) A fundamental review of the relationships between nanotechnology and lignocellulosic biomass. The nanoscience and technology of renewable biomaterials, vol 1. Wiley, New York, pp 1-41. https://doi.org/10.1002/9781444307474.ch1

Wrighton K, Thrash J, Melnyk R, Bigi J, Byrne B-K, Remis J, Schichnes D, Auer M, Chang C, Coates J (2011) Evidence for direct electron transfer by a Gram-positive bacterium isolated from a microbial fuel cell. Appl Environ Microbiol 77:7633-7639. https://doi.org/10.1128/aem.05365-11

Xiao B, Yang F, Liu J (2013) Evaluation of electricity production from alkaline pretreated sludge using two-chamber microbial fuel cell. J Hazard Mater 254:57-63. https://doi.org/10.1016/j.jhazmat.2013.03.039
Xu C, Poon K, Choi M-M, Wang R (2015) Using live algae at the anode of a microbial fuel cell to generate electricity. Environ Sci Pollut Res 22:1562115635. https://doi.org/10.1007/s11356-015-4744-8

Yong YC, Yu YY, Yang Y, Liu J, Wang JY, Song H (2013) Enhancement of extracellular electron transfer and bioelectricity output by synthetic porin. Biotechnol Bioeng 110:408-416. https://doi.org/10.1002/bit.24732

Yong YC, Yu YY, Zhang X, Song H (2014) Highly active bidirectional electron transfer by a self-assembled electroactive reduced-graphene-oxidehybridized biofilm. Angew Chem Int Ed 53:4480-4483. https://doi. org/10.1002/anie.201400463

Yu YY, Wang YZ, Fang Z, Shi YT, Cheng QW, Chen YX, Shi WD, Yong YC (2020) Single cell electron collector for highly efficient wiring-up electronic abiotic/biotic interface. Nat Commun 11:4087. https://doi.org/10.1038/ s41467-020-17897-9

Zang GL, Sheng GP, Tong ZH, Liu XW, Teng SX, Li WW, Yu HQ (2010) Direct electricity recovery from Canna indica by an air-cathode microbial fuel cell inoculated with rumen microorganisms. Environ Sci Technol 44:2715-2720. https://doi.org/10.1021/es902956e

Zhang J, Zhao Q, You S, Jiang J, Ren N (2008) Continuous electricity production from leachate in a novel upflow air-cathode membrane-free microbial fuel cell. Water Sci Technol 57:1017-1021. https://doi.org/10.2166/ wst.2008.063

Zhang Y, Min B, Huang L, Angelidaki I (2009) Generation of electricity and analysis of microbial communities in wheat straw biomass-powered microbial fuel cells. Appl Environ Microbiol 75:3389-3395. https://doi. org/10.1128/aem.02240-08

Zhang L, Li C, Ding L, Xu K, Ren H (2011) Influences of initial pH on performance and anodic microbes of fed-batch microbial fuel cells. J Chem Technol Biotechnol 86:1226-1232. https://doi.org/10.1002/jctb.2641

Zhang J, Zhang B, Tian C, Ye Z, Liu Y, Lei Z, Huang W, Feng C (2013) Simultaneous sulfide removal and electricity generation with corn stover biomass as co-substrate in microbial fuel cells. Bioresour Technol 138:198-203. https://doi.org/10.1016/.j.biortech.2013.03.167

Zhang L, Zhu X, Kashim H, Li J, Ye D, Liao Q, Regan JM (2015) Anolyte recirculation effects in buffered and unbuffered single-chamber aircathode microbial fuel cells. Bioresour Technol 179:26-34. https://doi. org/10.1016/j.biortech.2014.11.106

Zhao X, Liu W, Deng Y, Zhu J-Y (2017) Low-temperature microbial and direct conversion of lignocellulosic biomass to electricity: advances and challenges. Renew Sustain Energy Rev 71:268-282. https://doi.org/10.1016/j. rser.2016.12.055

Zhao N, Jiang Y, Alvarado MM, Treu L, Angelidaki I, Zhang Y (2018a) Electricity generation and microbial communities in microbial fuel cell powered by macroalgal biomass. Bioelectrochemistry 123:145-149. https://doi. org/10.1016/j.bioelechem.2018.05.002

Zhao Y, Ma Y, Li T, Dong Z, Wang Y (2018b) Modification of carbon felt anodes using double-oxidant $\mathrm{HNO}_{3} / \mathrm{H}_{2} \mathrm{O}_{2}$ for application in microbial fuel cells. RSC Adv 8:2059-2064. https://doi.org/10.1039/C7RA12923H

Zhao J, Li F, Cao Y, Zhang X, Chen T, Song H, Wang Z (2020) Microbial extracellular electron transfer and strategies for engineering electroactive microorganisms. Biotechnol Adv 14:107682. https://doi.org/10.1016/j. biotechadv.2020.107682

Zheng X, Nirmalakhandan N (2010) Cattle wastes as substrates for bioelectricity production via microbial fuel cells. Biotechnol Lett 32:1809-1814. https://doi.org/10.1007/s10529-010-0360-3

Zuo Y, Maness PC, Logan BE (2006) Electricity production from steamexploded corn stover biomass. Energy Fuel 20:1716-1721. https://doi. org/10.1021/ef060033|

\section{Publisher's Note}

Springer Nature remains neutral with regard to jurisdictional claims in published maps and institutional affiliations. 